\title{
Alternatives for Youth's Advocacy Program:Reducing Minority Youth Incarceration Placements in Cleveland, Ohio
}

Christopher A. Mallett

Cleveland State University, c.a.mallett@csuohio.edu

Linda Julian

Youth's Advocacy Program, Cleveland, $\mathrm{OH}$

Follow this and additional works at: https://engagedscholarship.csuohio.edu/clsowo_facpub

Part of the Juvenile Law Commons, Law Enforcement and Corrections Commons, and the Social Work Commons

How does access to this work benefit you? Let us know!

\section{Publisher's Statement}

This is the accepted version of the article which has been published in final form at http://onlinelibrary.wiley.com/doi/10.1111/j.1755-6988.2008.00016.x/full

\section{Recommended Citation}

Mallett, Christopher A. and Julian, Linda, "Alternatives for Youth's Advocacy Program:Reducing Minority Youth Incarceration Placements in Cleveland, Ohio" (2008). Social Work Faculty Publications. 16. https://engagedscholarship.csuohio.edu/clsowo_facpub/16

This Article is brought to you for free and open access by the School of Social Work at EngagedScholarship@CSU. It has been accepted for inclusion in Social Work Faculty Publications by an authorized administrator of EngagedScholarship@CSU. For more information, please contact library.es@csuohio.edu. 


\title{
Alternatives for Youth's Advocacy Program: Reducing Minority Youth Incarceration Placements in Cleveland, Ohio
}

\author{
By Christopher A. Mallett and Linda Julian
}

\begin{abstract}
Detaining and incarcerating juvenile delinquents is ineffective and costly juvenile justice policy. These placements, indicative of the "tough on crime" approach, become problematic for many of these youths who do not have the advantage of legal counsel because they waive this right. In addition, a majority of these youths have a mental health or special education disability that does not get addressed in correctional facilities. Alternatives for Youth's Advocacy Program (AFY) in Cleveland, Ohio (Cuyahoga County) is addressing these issues using a holistic approach that includes the provision of civil legal representation to assist youths in accessing disability services and defense attorney support in dispositional planning to reduce juvenile offender placements. This article reports the results of an experimental design pilot study evaluation of AFY that randomly referred and evaluated 82 felony-offending youths over 21 months. This initial review of the AFY program found it reduced detention center placement days by $47 \%$ and decreased state facility incarceration days by $74 \%$ (total cost savings $\$ 625,898$ ). With 3,000 youths detained in the Cuyahoga County, Ohio, Detention Center and 1,800 incarcerated in Ohio state facilities annually, policy implications and recommendations are set forth.
\end{abstract}

\section{JUVENILE JUSTICE POLICY PROBLEMS}

This article reports the initial results of an innovative legal advocacy program representing primarily minority, felony-offending youths within Cuyahoga County (greater Cleveland), Ohio's juvenile court.

Christopher A. Mallett, Esq., Ph.D., LISW, is Assistant Professor at Cleveland State University's School of Social Work, Cleveland Ohio. Correspondence: c.a.mallett@csuohio.edu.

Linda Julian, Esq., is Executive Director of Alternatives for Youth's Advocacy Program in Cleveland, Ohio. 


\section{Delinquency, Disabilities, and Detention}

On an average day in the United States, 54,500 youths are incarcerated in this country's detention or correctional institutions. This total includes 23,400 youths held in detention facilities awaiting trial or case disposition, and 31,100 youths incarcerated in juvenile correctional facilities pursuant to court-ordered sentence (Office of Juvenile Justice and Delinquency Prevention, 2003; Sickmund, Sladky, \& Kang, 2004). Of the 1,615,400 youths adjudicated delinquent nationwide in 2002 (Stahl, 2006), a total of 350,000 were held in 591 detention centers (Holman \& Ziedenberg, 2006; Sickmund et al., 2004), and 102,388 were held in 2,964 correctional facilities (Sickmund, 2006).

Access to mental health and special education services is important to help young people avoid future delinquent acts and possibly incarceration in juvenile corrections or the adult criminal system. The access is necessary because the majority of youths in detention have at least one significant disability that is not addressed (American Bar Association, 2007a). Between $40 \%$ and $90 \%$ of delinquent youths within these facilities have mental health disorders (Boesky, 2002; Lexcon \& Redding, 2002; Plisaka, Sherman, Barow, \& Irick, 2002; Rosado \& Shas, 2004; Teplin et al., 2006); between 37\% and 73\% have substance abuse disorders (Archwarnety \& Katsiyannis, 1998; Brunelle, Cousineau, \& Brochu, 2000; Garland et al., 2001; National Institute of Justice, 2003); and between $33 \%$ and $41 \%$ have special education disabilities (Burrell \& Warboys, 2000; Malmgren, Abbott, \& Hawkins, 1999; Mears \& Aron, 2003; National Council on Disability, 2002). These problems range from moderate to severe diagnoses and include depression/ dysthymia, affective disorders, bipolar disorder, mood disorders, psychosis, attentiondeficit hyperactivity disorder, substance (alcohol and drug) abuse disorders, learning disabilities, and developmentally handicapped disabilities (American Psychiatric Association, 2000; Individuals with Disabilities in Education Act, 2004).

Without preventive efforts and intervention services, many youths within the juvenile justice population will have their disabilities neither identified nor treated within other youth systems (mental health, substance abuse, and special education). Without treatment and disability systems coordination, juvenile detention and correctional facility placement is often the outcome (American Bar Association, 2007a; Mears \& Aron, 2003; Roberts, 2004; Stroul, Pires, \& Armstrong, 2000). These placements harm the youths and their communities, as discussed next.

\section{Dangers of Incarceration}

Most youths never have contact with the juvenile justice system. If a youth does come into contact, $54 \%$ of males and $70 \%$ of females will never have a second contact (Skowyra \& Cocozza, 2001). However, for detained youths, $70 \%$ can expect to be rearrested or returned to detention within one year of their release (Bezruki, Varana, \& Hill, 1999). Incarcerating juvenile offenders for pre-trial detention or to secure correctional institutions is ineffective and harmful public policy (Rosch \& Lederman, 2006) that compromises public safety (Holman \& Ziedenberg, 2006). 
The experience of detention makes it more likely that detained youths will continue to engage in delinquent behavior, and may increase the odds that youths will recidivate (Holman \& Ziedenberg, 2006; Torres \& Ooyen, 2002). Detained youths are more likely than non-detained youths to further penetrate the juvenile justice system, with prior commitment being the most significant predictor of recidivism: a youth with a prior commitment has a 13.5 times increased risk of a second secure facility placement (Benda \& Tollet, 1999).

Deviant behavior is increasingly found to be contagious among adolescents, particularly early adolescents (Dodge, Dishion, \& Landsford, 2006a; 2006b). Recent findings have identified significantly higher levels of substance abuse, school difficulties, delinquency, violence, and adjustment difficulties in adulthood for youths treated in deviant peer group settings (Dishion, McCord, \& Poulin, 1999). Detaining youths also has a profound negative impact on juveniles' education, mental and physical well-being, future employment, and workforce stability (Cohen, 1998; Forrest, Tambor, Riley, Ensminger, \& Starfield, 2000; Holman \& Ziedenberg, 2006; Males, Macallair, \& Corcoran, 2006). Time spent in detention interrupts positive peer, family, and school relations, while promoting a negative peer culture. Many detained youths with special needs fail to return to school (Holman \& Ziedenberg, 2006). These negative outcomes disproportionately impact minority youths (Poe-Yamagata \& Jones, 2000).

\section{Disparate Effects on Minority and Disabled Youths}

Detention and correctional facilities have an overrepresentation of minority youths and youths with disabilities (Mears \& Aron, 2003; National Institute of Justice, 2003; Teplin et al., 2006). Minority youths make up only one-third of the population but account for two-thirds of youths in long-term care facilities, and are more likely to be incarcerated than non-minority youths for the same types of offenses (Poe-Yamagata \& Jones, 2000). Programs designed to keep youths out of secure facilities often fail to serve the needs of minority youths. For example, Ohio's RECLAIM (Reasoned \& Equitable Community \& Local Alternatives to the Incarceration of Minors) funding initiatives, which provide financial support to local jurisdictions to develop alternative programs to reduce the number of youths incarcerated in state facilities, served primarily white youths (80\%; Lowenkamp \& Latessa, 2005). In addition, a majority of detained or incarcerated youths have a diagnosable mental health disorder, compared to only $9 \%$ to $16 \%$ of the general youth population (Center for Mental Health Services, 2004; Teplin et al., 2006). At least one-third of detained or incarcerated youths have a special education disability, compared to only $4 \%$ to $10 \%$ of the general youth population (Mears \& Aron, 2003; National Council of Juvenile and Family Court Judges, 2003; U.S. Department of Education, 2004).

\section{Need for Legal Representation}

Accused delinquents' right to counsel was established in 1967 (In re Gault, 387 U.S. 1, 87 S. Ct. 1428). In response to many concerns about youths within the juvenile 
justice system and this Supreme Court decision, Congress enacted the Juvenile Justice and Delinquency Prevention Act (JJDPA, 42 U.S.C. § 5601 et seq., Public Law 93-415, 1972), and the American Bar Association proposed juvenile justice administration standards (Institute for Judicial Administration, 1980). The JJDPA provides federal funding to prevent and reduce delinquency, while the ABA standards provide guidelines for legal representation of juveniles from the earliest court processes.

Significant disparity exists today between states and counties in achieving this standard that all accused delinquents be represented by counsel (Jones, 2004). In some jurisdictions, more than $70 \%$ of youths waive their right to counsel early in the juvenile justice process, forgoing any possible future representation (American Bar Association, 2007b; Feld, 1990; U.S. Government Accounting Office, 1995). The American Bar Association Juvenile Defender Center's ongoing review of state efforts to address juveniles' right to counsel continues to find similar shortcomings in availability and quality of legal representation in Georgia, Kentucky, Louisiana, Maine, Maryland, Montana, North Carolina, Ohio, Pennsylvania, Texas, Virginia, and Washington (Shepherd, 2003). These shortcomings are highly problematic, for defense counsel assists not only in legal representation but in advocating for necessary mental health (including substance abuse) and special education disability services (Puritz, Burrell, Schwartz, Soler, \& Warboys, 2002). The state of Ohio recently recognized, though prompted by a Federal class action lawsuit settlement, the right to counsel for juveniles in state facilities who are making claims concerning their detention length and conditions (Ghose, 2007). After this settlement, a Justice Department investigation found that these facilities were still not offering sufficient rehabilitative care, resulting in longer incarceration stays (U.S. Department of Justice, 2007).

Many youths who are eventually detained or incarcerated have waived their right to defense counsel (American Bar Association, 2007b; Jones, 2004). But when counsel is not waived, juvenile offenders' access to representation is impeded by a number of factors including inconsistent and at times non-existent appointment of counsel; increasing delinquency caseloads in juvenile courts and subsequently overburdened attorneys; low compensation levels that affect attorney recruitment and retention; and low levels of attorney training (Jones, 2004). Additionally, attorneys who represent these youths are often unprepared to deal with the multitude of issues that such representation entails.

Not having legal representation poses risks to these youths because counsel can improve the quality and types of treatment programs juvenile offenders access for services (American Bar Association, 2007b; Feld, 1990; U.S. Government Accounting Office, 1995). In fact, the Sentencing Project and Office of Juvenile Justice and Delinquency Prevention have identified effective juvenile representation to include valid and reliable youth evaluation assessments, knowledge of youth development, access to community services that address youths' special needs, access to information and experts, access and integration with community resources and experts, emphasis on youth risk and protective factors, integration and use of family strengths, and appropriate juvenile (not adult) defense strategies (OJJDP, 2004; Young and Gainsborough, 2000). 


\section{CONCEPTUAL FRAMEWORK}

In light of these difficult and problematic juvenile justice policy issues, efforts to address these placements, incarcerations, and disparities have been undertaken. For example, the Center for the Study and Prevention of Violence, the Office of Juvenile Justice and Delinquency Prevention, Washington State Institute for Public Policy, and several other research institutes have shown that increasing the numbers of programs and initiatives focused on identifying and treating disabilities reduces juvenile recidivism, detention, and crime in a cost-effective manner (Kamradt, 2001; Mendel \& Peterson, 2007; Osher, Rouse, Quinn, \& Woodruff, 2002; OJJDP, 2004).

In particular, the TeamChild model, recognized as one of six promising programs for juvenile delinquency prevention (OJJDP, 2004), advocates for education and health care needs through psychological assessment and treatment coordination. One study found the model to save $\$ 4,000$ per youth in juvenile court recidivism costs (Jones, 2004; Washington State Institute for Public Policy, 1998). Over the past decade, the Mental Health Juvenile Justice Diversion Project has shown a marked decrease in out-of-community placement and recidivism for $11 \mathrm{New}$ York counties through mental health and substance abuse screenings at probation intake, treatment provided in the county probation departments as needed, and links to appropriate community providers (Sullivan, Veysey, Hamilton, \& Grillo, 2007). Most recently, the Illinois Mental Health Juvenile Justice Initiative decreased arrest rates, increased school attendance, and improved functioning for youths with serious mental illness released from detention centers through coordinated community-based treatment (Illinois Juvenile Justice Mental Health Initiative, 2007; National Center for Mental Health and Juvenile Justice, 2008).

Improved outcomes for felony-offending youths are achieved through behavioral, social learning, and cognitive-behavioral treatment modality interventions (Lipsey, 1992; Gendreau, 1996) with fidelity to implementation of treatment amount, quality, personnel training, and close monitoring imperative for positive outcomes (Lipsey \& Wilson, 1998). Some additional common elements in proven service delivery programs for juvenile offender populations include treatment that occurs within the family or in a family-like setting; treatment that occurs at home or close to home; services that are delivered in a culturally respectful and competent manner; treatment that is built (intensely) around youth, family, and community strengths; and treatment that helps a wide range of appropriate services and resources for the youth and family (Gies, 2003; Holman \& Ziedenberg, 2006; National Center on Education, Disability, and Juvenile Justice, 2002; National Council of Juvenile and Family Court Judges, 2003; Young \& Gainsborough, 2000).

\section{Alternatives for Youth's Advocacy Program in Cleveland, Ohio}

The Alternatives for Youth's (AFY) Advocacy Program in Cleveland, Ohio, is modeled after TeamChild, a civil legal advocacy project for juvenile justice systeminvolved youths. In the TeamChild (and AFY) model, legal representation is provided for youths involved in the juvenile justice system to assist them in accessing services (special education, health care, and safe living situations). AFY has applied this model to include 
links to community-based programs through development of collaborative partnerships with service providers and support for defense attorneys in dispositional planning and advocacy both in and out of the courtroom.

AFY works with youths and their families to develop a youth-directed plan for success that is designed to reduce time spent in pre-trial detention and avoid dispositional sentences to incarceration. AFY uses principles of therapeutic jurisprudence to make this a learning experience for the youths while empowering them to make decisions that will provide positive outcomes. This process is designed to facilitate the active participation of youths in their treatment and educational services. Once a plan is designed, AFY assists the youths and families with implementation, connecting them to needed services in the community, and advocating for special educational needs and other entitlement services.

Youths needing mental health evaluations are referred to the Juvenile Forensic Clinic, a partnership between AFY and University Hospital's Case Medical School's Department of Child and Adolescent Psychiatry, which provides diagnostic evaluations to youths prior to adjudication. These evaluations provide proper diagnoses and make treatment recommendations for these youths. This model ensures timely diagnosis and treatment while protecting the youth's privilege against compulsory self incrimination. The diagnostic report is released to AFY, which consults with the youths and their families about treatment recommendations and then assists in accessing necessary community-based services. The report, recommendations, and treatment services are shared with the youths' defense attorneys to assist them in case advocacy. The defense attorneys use this information primarily for dispositional purposes, but it may also be helpful in addressing pretrial detention or competency issues. AFY also provides assistance and legal representation for accessing special educational services and assisting with issues related to living situations that may involve custody to relatives or the Department of Children and Family Services.

In addition, AFY provides support for defense attorneys who advocate for their clients at detention hearings, amenability hearings, and dispositional hearings. AFY's staff, which consists of an attorney and social work team, provides support to the family at court hearings and helps the defense attorney explain to the court the youth's needs and the progress being made in addressing those needs. This support is a very helpful component because many attorneys and judges are unfamiliar with specific mental health diagnoses and treatment and with the process necessary to access special educational services. Two case examples help to illustrate the AFY program process.

A 17-year-old African-American male was charged with two counts of Felonious Assault, a one- and three-year firearm specification (F-2), and one count of Carrying a Concealed Weapon (F-4). The young man was facing a discretionary bindover or state (ODYS) incarceration. After finding probable cause that the crime was committed, the youth was entitled to an amenability hearing which required the prosecution prove that the youth was not amenable to treatment in the juvenile justice system. At the hearing, AFY's social worker had the opportunity to testify providing information regarding the youth's mental health and substance abuse diagnosis, and the failure of the juvenile justice system to provide him previously with appropriate interventions. University 
Hospitals (referred by AFY) conducted a psychological evaluation that indicated a diagnosis of Attention-Deficit/Hyperactivity Disorder, Cannabis Dependence, and Conduct Disorder. The judge found that this youth was amenable to treatment in the juvenile justice system and continued the juvenile court jurisdiction. After the trial, during which he was convicted of the weapon charge, the youth was released from the detention center, placed on probation, and referred to community-based, intensive outpatient drug treatment, in which he is currently participating.

In the second case, a 16-year-old African-American male had numerous felony charges pending, including Aggravated Burglary (F-1), Felonious Assault (F-2), Abduction (F-3), and Aggravated Menacing (M-1). Based on information gathered from the youth and family, an undiagnosed mental health disorder was suspected. An evaluation referral was therefore made to University Hospitals, and the young man was diagnosed with Dysthymic Disorder and recommended medication and counseling treatment. The young man was adjudicated on several charges, and a referral was made for in-home family therapy and psychiatric treatment through University Hospitals. At the disposition hearing, this plan was presented to the judge. The young man was terminated from probation (he was already on probation for prior charges) and was able to remain in the community with the recommendation that he follow through with the mental health services.

To determine whether the AFY services are effective, or if these case examples are unique, an initial evaluation of the program for high-risk felony offenders in Cuyahoga County is being undertaken. This project has primarily served male, minority youths, over 16 at the time of offense, and charged with first- or second-degree felonies. Alternatives to incarceration are vital in Cuyahoga County, Ohio (greater Cleveland-with a youth population of 264,637 , U.S. Census Bureau, 2006). In 2004, the courts had 8,667 youths (including $66 \%$ minorities) adjudicated delinquent. Of this total, 3,102 youths were held in the detention center (daily population of 125; 12-day average length of stay), and 491 youths (including $74 \%$ minorities) were incarcerated in locked county or state correctional facilities at some point during the year (Cuyahoga County Juvenile Court, 2005). Throughout the state, youths incarcerated in Ohio are particularly at risk because $71 \%$ have a mental health disability, $70 \%$ have a drug addiction, and $49 \%$ have a special education disability (Ohio Department of Youth Services, 2006; 2007).

This study design compares current legal representation for felony-offending youths in Cuyahoga County with the AFY model. If results are positive, this study would show that the AFY model of legal advocacy which is focused on education and mental health needs is directly linked to improved offender outcomes compared to the traditional public defender and/or court-appointed representation.

\section{RESEARCH METHODOLOGY}

\section{Research Question}

This initial experimental design pilot evaluation of the Alternatives for Youth's Advocacy Program took place over 21 months (September 15, 2005 to June 30, 2007), 
and posed the following research question: Does the AFY program cause a decrease in pre-disposition detention of youths and sentences to state correctional facilities?

Research question variables were defined as "Pre-dispositional detention" which included number of days in detention (post study referral date) and readmission to detention (while the current charge is pending, post study referral date); and "state correctional facilities" was placement in a state incarceration facility. Additional measurements of the AFY program activities in this study included "mental health," which was any treatment service provided to address mental health or substance abuse disorders; "special education," which included advocacy and legal representation to the school district, identification of special education needs, individualized education plan (IEP) representations, and re-enrollment in school/alternative school placements; and "vocational," which included employment training programs and pro-social/vocational activities.

\section{Population, Experimental Group, and Control Group}

The study population included all detention center-residing youths (at arraignment), who had at least one felony charge (F1 to F5) from September 15, 2005 to February 5, $2007(\mathrm{~N}=820)$. Youths with domestic violence charges, mandatory bindover commitments to criminal court, or referrals to the SCY (Strengthening Community Youth) program were excluded. Mandatory bindover youths were excluded because they were prosecuted within the adult criminal court system. SCY program-referred youths (only 30 per year) were excluded because they were already receiving drug assessments and treatment services. Domestic violence charges were excluded because they represent a skewed, large percentage of cases arraigned at the detention center because the current practice in Cuyahoga County requires one individual to be arrested for every domestic violence police call. Many of these initial domestic violence charges are eventually dismissed, necessitating this study exclusion.

A systematic random referral from this detention center population was drawn from the Cuyahoga County Public Defender's intake office, which referred every $10^{\text {th }}$ youth arraigned beginning September 15, 2005 and ending February 5, 2007. The first referral (number 10) was to AFY services (experimental group), the next referral (number 20) was not referred to AFY services (control group), the next referral (number 30) was referred to AFY services (experimental group), and so on. Over the 21-month program evaluation time period, 41 youths were referred to the AFY program (experimental group) and 41 youths were referred to the comparable group that did not receive AFY services (control group).

All youths were represented in their delinquency cases by the public defender's office at the time of arraignment. After arraignment, youths either received continued representation from the public defender's office or were assigned an attorney from the assigned counsel list. This decision was made by the assigned judge. In addition to the representation by the public defender's office or assigned counsel, the experimental group received services through AFY. The control group proceeded through the court process in the manner in which most cases proceed through the juvenile court. Those in the control 
group who were under 18 and still involved with or re-involved with the juvenile justice system after 12 months were offered AFY services. The control and experimental group outcome measures were matters of public record held within the public domain. Consent for AFY services was provided by youths and parents or guardians at the time of service initiation.

\section{Data Analysis and Statistical Tests}

Data were collected for each youth from his or her date of study inclusion through March 1, 2007, and for pre-dispositional detention and incarceration through June 30, 2007. Detention center and state facility placement, total number of days in detention and state facilities, and detention center re-admissions were tracked. An independent t-test (ratio level of measurement; parametric assumptions) was used to determine whether the difference between the experimental and control groups number of days detained was statistically significant. A chi square test (dichotomous level of measurement, non-parametric assumptions) was used to determine whether the differences found between the experimental and control groups detention and state facility placements and detention re-admission rates were statistically significant. If the differences were statistically significant $(<.05)$, a cost-benefit analysis was computed to determine the cost-savings attributed to the AFY Program's impact.

\section{PROGRAM EVALUATION FINDINGS}

This section first presents group comparison characteristics and AFY accessed services, followed by group detention and incarceration placement comparison findings.

\section{Experimental and Control Group Characteristics}

Youths randomly referred to both the experimental (AFY) and control (non-AFY) groups were very similar. The 41 youths who received AFY services were overwhelmingly male (93.0\%), minority (87.8\% African American; 2.2\% Hispanic American; $10.0 \%$ Caucasian), and older at the time of offense (20.4\% under 14 years of age; $25.3 \%$ age 15 ; $27.7 \%$ age 16 ; and $26.5 \%$ age 17 ). These youths' offense level was primarily first (F1)and second (F2)-degree felonies $(29.0 \% \mathrm{~F} 1 ; 30.0 \% \mathrm{~F} 2 ; 4.0 \% \mathrm{~F} 3 ; 29.0 \% \mathrm{~F} 4$; and $7.0 \%$ F5). The 41 youths who did not receive AFY services were overwhelmingly male (95.0\%), minority (85.4\% African American; $14.6 \%$ Caucasian), and older at the time of offense (17.1\% under 14 years of age; $26.8 \%$ age $15 ; 26.8 \%$ age 16 ; and $29.3 \%$ age 17 ). The offense levels for the comparison group were also primarily first (F1)- and second (F2)-degree felonies (31.7\% F1; 29.3\% F2; 7.3\% F3; 21.9\% F4; and 9.8\% F5).

\section{Experimental Group Accessed Services}

Over $58 \%$ of AFY-involved youths received at least one mental health, special education, or vocational service (see Table 1). Almost $25 \%$ of these youths received a 
TABLE 1

AFY Accessed Services

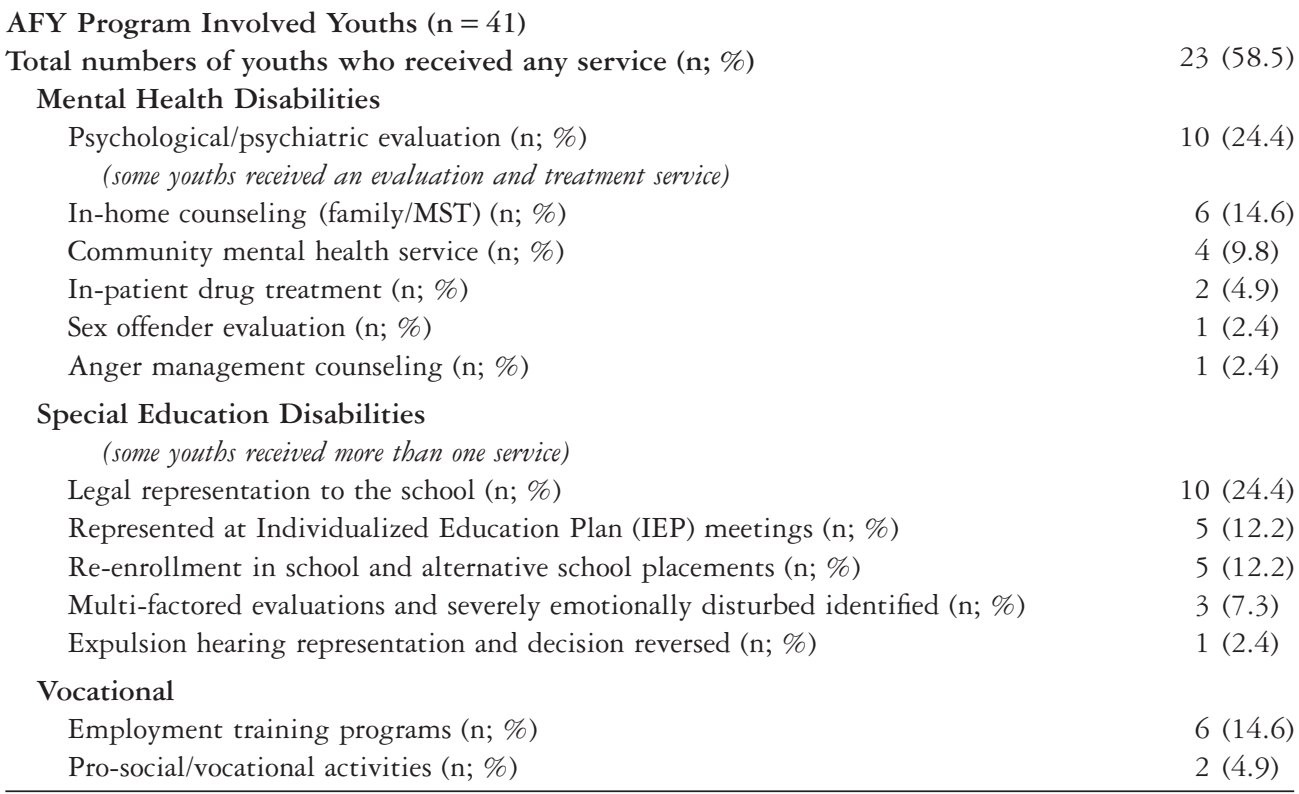

psychological or psychiatric evaluation, and over $35 \%$ received mental health or drug/ alcohol treatment services. AFY provided advocacy and legal representation to school districts for almost $25 \%$ of the youths, resulting in the identification of special education needs (7.3\%), individualized education planning advocacy (12.2\%), and the re-enrollment or placement of the youths in alternative school settings (12.2\%). AFY provided almost $20 \%$ of the youths with employment training programs or other vocational-related activities.

\section{Experimental Group}

The AFY program resulted in significantly reduced sentences to state correctional facilities and reductions in average detention center placement days (see Table 2). However, while reducing the percentage of youths placed in detention, this reduction was not found to be significant. These fewer placement days that AFY-involved youths were not detained or incarcerated represented a total $\$ 625,898$ cost savings during this 21-month period when compared to the non-involved youths. More specifically, the total number of days in detention for AFY-involved youths decreased by $46.8 \%$, representing a corresponding cost savings of $\$ 222,500$. Of these detention center-placed youths, the length of stay for those involved with AFY was on average 24 days shorter.

No AFY-involved youth was re-admitted to the detention center during this evaluation time frame, while eleven $(27.3 \%)$ of the youths not receiving AFY services were re-admitted. Just as important, there was a $74.5 \%$ decrease in number of state 
TABLE 2

Correctional Facility Placement Outcomes

\begin{tabular}{|c|c|c|c|c|}
\hline & $\begin{array}{c}\text { Experimental } \\
(A F Y) \text { Group } \\
(n=41)\end{array}$ & $\begin{array}{c}\text { Control Group } \\
(n=41)\end{array}$ & $\begin{array}{l}\text { Statistical } \\
\text { Significance }\end{array}$ & $\begin{array}{c}\text { AFY Program } \\
\text { Cost-benefit } \\
\text { Analysis }(9 / 15 / 05 \\
\text { to } 6 / 30 / 07)\end{array}$ \\
\hline \multicolumn{5}{|l|}{$\begin{array}{l}\text { Pre-dispositional } \\
\text { Detention } \\
\text { (current as of March 1, } \\
\text { 2007) }\end{array}$} \\
\hline $\begin{array}{l}\text { Detention center } \\
\qquad(\mathrm{n} ; \% ; \# \text { total days })\end{array}$ & $\begin{array}{c}19(46.3) \\
1,015\end{array}$ & $\begin{array}{c}25(61.0) \\
1,905\end{array}$ & $\begin{array}{l}<.184 \\
\text { Chi Square test: } X 2 \\
(\mathrm{df}=1)=1.766\end{array}$ & $\begin{array}{l}\$ 222,500 \\
(1,905 \text { days less } 1,015 \\
\text { days }=890 \text { days at } \\
\$ 250.00 / \text { diem }=\end{array}$ \\
\hline $\begin{array}{l}\text { Detention } \\
\text { re-admission } \\
(\mathrm{n} ; \%)\end{array}$ & 0 & $11(27.3)$ & $\begin{array}{l}<.001 \\
\text { Chi Square test: } X 2 \\
(\mathrm{df}=1)=12.74 \\
2 \text { cells }<5\end{array}$ & $\$ 222,500)$ \\
\hline $\begin{array}{l}\text { Average detention } \\
\text { center stay (days) }\end{array}$ & 29.6 & 54.2 & $\begin{array}{l}<.016 \\
\text { Ind. Samples t-test } \\
(\mathrm{df}=79)=2.46\end{array}$ & \\
\hline $\begin{array}{l}\text { State correctional } \\
\text { facilities (ODYS) } \\
\text { (n; \%; \# total days) } \\
\text { (total days extrapolated } \\
\text { from date of state facility } \\
\text { placement to June } 30, \\
\text { 2007) }\end{array}$ & $\begin{array}{r}3(7.3) \\
629\end{array}$ & $\begin{array}{c}12(29.2) \\
2,471\end{array}$ & $\begin{array}{l}<.01 \\
\text { Chi Square test: } X 2 \\
(\mathrm{df}=1)=6.61 \\
2 \text { cells }<5\end{array}$ & $\begin{array}{l}\$ 403,398 \\
(2,471 \text { days less } 629 \\
\text { days }=1,842 \text { days at } \\
\$ 219.00 / \text { diem }= \\
\$ 403,398)\end{array}$ \\
\hline
\end{tabular}

correctional facility placement days, with only three of the AFY-involved youths (7\%) incarcerated (for a total of 629 days) compared to over 29\% (12) of the non-involved youths (for a total of 2,471 days; corresponding cost savings of $\$ 403,398$ ). These findings are preliminary because the comparative group sample sizes are relatively small.

\section{DISCUSSION}

Half the youths involved with the AFY program were in need of mental health and/or special education disability services, provided for through the program's advocacy and representation efforts. These disability and vocational services that evaluations, family work, and legal advocacy efforts identified helped many of the youths avoid further juvenile justice system penetration. While no panacea, the addition of the AFY program provided these youths with efforts and advocacy comparable to what all offenders receive from the public defender's office (or assigned counsel) and subsequently from the juvenile court; however, AFY acted in a more timely and thorough fashion, giving each youth and family the opportunity to identify current needs. This initial program evaluation 
population was almost exclusively minority (over 90\%) already residing within the Cuyahoga County Detention Center at time of AFY admission. Many of these youths and many potential delinquent youths might be able to avoid or minimize detention and incarceration outcomes through earlier disability identification and treatment, coordination, and legal advocacy efforts similar to the AFY program.

These AFY evaluation findings in Cuyahoga County, Ohio, demonstrate the program's initial effectiveness at reducing state incarcerations, detention center re-admission placements, and detention center placement lengths for this population. A clear exception to these positive findings, however, was the lack of difference in overall detention center placements for these youths. A possible explanation, though not empirically identified, as to why these initial detention center placement rates were not significantly reduced was because AFY became involved with many youths at the time of detention center placement, precluding earlier advocacy. Even so, these encouraging results are considered preliminary, for this pilot study should be continued to determine whether there is a long-term AFY impact.

The AFY program outcomes support ongoing, broad-based policy efforts to address detention and incarceration concerns and recidivism rates, particularly for minority youths (Poe-Yamagata \& Jones, 2000), and to find cost-effective preventive efforts for this highly at-risk population (Holman \& Ziedenberg, 2006). Continued coordination and expansion of preventive programs and evaluations to identify effective programs are championed by the National Council on Crime and Delinquency supported by the Office of Juvenile Justice and Delinquency Prevention (Krisberg, Barry, \& Sharrock, 2007). In Ohio, Attorney General Mark Dann applauded some of the state's delinquency prevention efforts to date, but stated that the detention program must be "fixed, changed from its current prison-like atmosphere" and that Ohio should close its large state institutions in favor of smaller centers (Ghose, 2007). This contention was supported by a recent independent fact-finder appointed because a federal lawsuit filed against the Ohio Department of Youth Services found "most facilities . . . were overcrowded, understaffed, and underserved in such vital areas of safety, education, mental health treatment, and rehabilitative programming" (Cohen, 2008).

This is a challenging order. Over 80 jurisdictions in 20 states and the District of Columbia have shown success in moving from larger facilities and incarcerations to community-based supervision (Annie E. Casey Foundation, 2008). However, most states and jurisdictions (of which there are over 1,300) continue to use larger detention and incarceration facilities. Reasons stated for this utilization included the lack of other developed options in the best interest of the youth and community, even though it is generally recognized these facilities at best do not improve youth and family outcomes and often times harm the youth (OJJDP, 2004).

In many at-risk youth populations, including juvenile justice, early disability identification has been found to be important in decreasing later poor and criminal outcomes because coordination efforts among disability systems can share resources and efforts (Klitzner, Fisher, Stewart, \& Gilbert, 1991; Mears \& Aron, 2003; Roberts, 2004; Stroul et al., 2000). However, efforts to identify disabilities in early-offending youths within the juvenile justice system may have a net-widening impact-expanding the 
number and types of youths brought under juvenile court supervision (Ezell, 1989; Mears, 2000; Oldenettel \& Wordes, 2000). The payoff for early disability identification could be significantly improved systems (funding) coordination and less juvenile justice system penetration, while the challenge could be an inability to get systems to coordinate resulting in funding battles, service gaps, and youths going without treatment. Today, though, more positive outcomes look to be identified with the earlier disability screening and identification approach for this population (Benda \& Tollet, 1999; Holman \& Ziedenberg, 2006; Mears \& Aron, 2003).

\section{Study Limitations}

This research project was a pilot evaluation of a novel juvenile justice approach to reducing delinquency, detention, and state incarceration of primarily minority youths in the greater Cleveland, Ohio area. The comparative sample sizes are relatively small and subsequent findings should be considered preliminary, and needing continuation and replication. Some chi square statistical tests had cells less than five, so caution is warranted.

\section{Directions for Future Research}

These results contribute to the research literature that has found identification of disabilities and provision of treatment services for this population to be effective in reducing juvenile recidivism and incarceration (Mears \& Aron, 2003; Roberts, 2004). However, the number of studies completed to date for the juvenile felony-offending population is limited, although much effort and resources are focused on the problems (OJJDP, 2004). Research should continue to identify the prevalence rates of these disabilities within juvenile justice populations across jurisdictions, to determine the epidemiological extent of the problem; research should then begin a discussion of court and community resource (re)allocation. Until jurisdictions and states know the extent of youth disabilities within their juvenile courts, accurate planning cannot follow. Epidemiology to date has utilized locked facilities as research populations; this work should continue but expand to include non-secure population studies. Once identified, continued research designs using at least comparison groups must be used with both the detained and non-detained youth populations. These steps could then determine treatment, sanction, and program efforts that may be effective in avoiding further or continued youth juvenile court involvement and system penetration.

\section{REFERENCES}

American Bar Association. (2007a). ABA president elect youth at risk initiative. Available at http:// www.abanet.org/youthatrisk/.

American Bar Association Juvenile Justice Center. (2007b). Available at http://www.abanet.org/dch/ committee.cfm?com =CR200000. 
American Psychiatric Association. (2000). The diagnostic and statistical manual of mental disorders-IVtext revision. Washington DC: American Psychiatric Association Press.

Annie E. Casey Foundation. (2008). Juvenile detention alternatives initiative (JDAI). Available at http:// www.aecf.org/MajorInitiatives/JuvenileDetentionAlternativesInitiative.aspx.

Archwarnety, Teara, \& Katsiyannis, Antonis. (1998). Factors related to recidivism among delinquent females at a state correctional facility. Journal of Child and Family Studies, 7(1), 59-67.

Benda, B. B., \& Tollet, C. L. (1999). A study of recidivism of serious and persistent offenders among adolescents. Journal of Criminal Justice, 27(2), 111-126.

Bezruki, D., Varana, D., \& Hill, C. (1999). An evaluation of secure juvenile detention. Madison, WI: Legislative Audit Bureau. Available at http://www.legis.state.wi.us/LAB/reports/99-13full.pdf.

Boesky, Lisa. (2002). Juvenile offenders with mental health disorders: Who are they and what do we do with them?, 4, American Correctional Association.

Brunelle, Natacha, Cousineau, Marie, \& Brochu, Serge. (2000). Drug-crime relations among drugconsuming juvenile delinquents: A tripartite model and more. Contemporary Drug Problems, 27(4), $835-867$.

Burrell, Sue, \& Warboys, Lauren. (2000). Special education and the juvenile justice system. Washington DC: U.S. Department of Justice, Office of Juvenile Justice and Delinquency Prevention.

Center for Mental Health Services. (2004). Mental health, United States. Washington DC: U.S. Department of Health and Human Services, Public Health Service.

Cohen, Fred. (2008). Final fact-finding report, S.H. v. Strickrath. Available at http://www.dys.ohio.gov/ dysweb/PressReleases/CohenReport/CONSULTANT\%20REPORT\%2012-31-2007.pdf.

Cohen, Mark A. (1998). The monetary value of saving a high risk youth. The Journal of Qualitative Criminology, 14(1), 5-33.

Cuyahoga County, Ohio Juvenile Court. (2004; 2005). Annual report(s). Available at http:// juvenile.cuyahogacounty.us/annualreport.htm.

Dishion, T. J., McCord, J., \& Poulin, F. (1999). When interventions harm: Peer groups and problem behavior. American Psychologist, 54(9), 755-764.

Dodge, K. A., Dishion, T. J., \& Landsford, J. E. (Eds). (2006a). Deviant peer influences in programs for youth. New York: Guilford Press.

Dodge, K. A., Dishion, T. J., \& Landsford, J. E. (2006b). Deviant peer influences in intervention and public policy for youth. Social Policy Report, 20(1).

Ezell, Mark. (1989). Juvenile arbitration: Net widening and other unintended consequences. Journal of Research in Crime and Delinquency, 26(4), 212-223.

Feld, Barry. (1990). The punitive juvenile court and the quality of procedural justice: Distinctions between rhetoric and reality. Crime and Delinquency, 36, 443-458.

Forrest, C. B., Tambor, E., Riley, A. W., Ensminger, M. E., \& Starfield, B. (2000). The health profile of incarcerated male youths. Pediatrics, 105(1), 286-291.

Garland, Ann, Hough, Richard, McCabe, Christin, Yeh, May, Woods, Patricia, \& Aarons, Gregory. (2001). Prevalence of adolescent substance use disorders across five sectors of care. Journal of the American Academy of Child and Adolescent Psychiatry, 40(4), 419-426.

Gendreau, P. (1996). The principles of effective intervention with offenders. In A. Harland (Ed.), Choosing correctional options that work. Thousand Oaks, CA: Sage Publications.

Ghose, Carrie Spencer. (2007, May 27). Class-action suit alleges offenders in Ohio denied legal representation; State to set up formal program. Akron Beacon Journal.

Gies, Steve. (2003). Aftercare services. OJJDP, Juvenile Justice Bulletin. Available at http:// www.ncjrs.gov/pdffiles1/ojjdp/201800.pdf.

Holman, Barry, \& Ziedenberg, Jason. (2006). The dangers of detention: The impact of incarcerating youth in detention and other secure congregate facilities. Baltimore, MD: Annie E. Casey Foundation.

Illinois Juvenile Justice Mental Health Initiative. (2007). Available at http://www.ncmhjj.com/ Blueprint/programs/Illinois.shtml.

Individuals with Disabilities in Education Act. (2004 reauthorization). Available at http://frwebgate. access.gpo.gov/cgi-bin/getdoc.cgi? dbname =108_cong_public_laws\&docid=f:publ446.108.

Institute for Judicial Administration-American Bar Association (IJA-ABA). (1980). Juvenile justice standards, Washington DC: Author. 
Jones, Judith B. (June 2004). Access to counsel, Juvenile Justice Bulletin. Washington DC: U.S. Department of Justice, Office of Juvenile Justice and Delinquency Prevention.

Kamradt, B. (2001). Wraparound Milwaukee: Aiding youth with mental health needs. Juvenile Justice VII(1). Washington DC: Office of Juvenile Justice and Delinquency Prevention.

Klitzner, M., Fisher, D., Stewart, K., \& Gilbert, S. (1991). Report to the Robert Wood Johnson Foundation on strategies for early intervention with children and youth to avoid abuse of addictive substances. Bethesda, MD: Pacific Institute for Research and Evaluation.

Krisberg, Barry, Barry, Giselle, \& Sharrock, Emily. (2007). Reforming juvenile justice through comprehensive community planning. Oakland, CA: National Council on Crime and Delinquency.

Lexcon, F., \& Redding, R. E. (2002). Mental health needs of juvenile offenders. Juvenile Correctional Mental Health Report, 3(1), 1, 2, 8-16.

Lipsey, Mark. (1992). The effect of treatment on juvenile delinquents: Results from meta-analysis. In F. Losel, D. Bender, \& T. Bleisener (Eds.), Psychology and law: International perspectives. Berlin: Walter deGruyter.

Lipsey, Mark, \& Wilson, D. (1998). Effective intervention for serious juvenile offenders: A synthesis of research. In R. Loeber \& D. Farrington (Eds.), Serious and violent juvenile offenders: Risk factors and successful interventions. Thousand Oaks, CA: Sage Publications.

Lowenkamp, Christopher T., \& Latessa, Edward J. (2005). Evaluation of Ohio's RECLAIM funded programs, community corrections facilities, and DYS facilities. Available at http://www.dys. state.oh.us/dysweb/Reclaim/RECLAIMExecutiveSummaryAugust17.pdf.

Males, Mike, Macallair, Daniel, \& Corcoran, Megan D. (2006). Testing incapacitation theory: Youth crime and incarceration in California. San Francisco, CA: Center on Juvenile \& Criminal Justice. Available at http://www.cjcj.org/pdf/testing_incapacitation.pdf.

Malmgren, Karen, Abbott, Richard, \& Hawkins, David. (1999). Learning disability and delinquency: Rethinking the "link." Journal of Learning Disabilities, 32, 194-200.

Mears, Daniel. (2000). Assessing the effectiveness of juvenile justice reforms: A closer look at the criteria and the impacts on diverse stakeholders. Law E Policy, 22(2), 175-202.

Mears, Daniel, \& Aron, Laudan. (2003). Addressing the needs of youth with disabilities in the juvenile justice system: The current state of knowledge. Washington, DC: The Urban Institute. Available at http:// www.urban.org/publications/410885.html.

Mendel, Richard, \& Peterson, Julie. (2007). Pathways to juvenile detention reform: Beyond Detention (Series \#14). Available at http://www.aecf.org/KnowledgeCenter/Publications.aspx?pubguid $=$ \%7BCB481CEA-72CF-424F-BBF6-356C41DDC489\%7D.

National Center on Education, Disability, and Juvenile Justice. (2002). Best and promising practices for short-term jails and detention centers. EDJJ Notes, 1, 2-3.

National Center for Mental Health and Juvenile Justice. (2008). The Illinois mental health juvenile justice initiative. Available at http://www.ncmhji.com/Blueprint/programs/Illinois.shtml.

National Council on Disability. (2002). National disability policy: A progress report, December 2001December 2002. Washington, DC. Available at http://www.ncd.gov/newsroom/publications/2003/ progressreport_final.htm.

National Council of Juvenile and Family Court Judges, Juvenile Sanctions Center. (2003). Graduated sanctions for juvenile offenders: A program model and planning guide. Reno, NV: Author.

National Institute of Justice. (2003). Arrestee drug abuse monitoring: Annual report. Available at http:// www.ojp.usdoj.gov/nij/topics/drugs/adam.htm.

Office of Juvenile Justice and Delinquency Prevention. (2003). Census of juveniles in residential placement databook. Washington DC. Available at http://ojjdp.ncjrs.org/ojstatbb/cjrp/asp/ State_Adj.asp.

Office of Juvenile Justice and Delinquency Prevention. (OJJDP, 2004). Model program guide. Washington, DC: U.S. Department of Justice.

Ohio Department of Youth Services. (2006). Annual report. Available at http://www.dys.ohio.gov/ dysweb/Publications/Final\%20FY2006\%20Annual\%20Report.pdf.

Ohio Department of Youth Services. (2007). The responsibility of the juvenile justice system: Preparing incarcerated youth for academic success. Governor's Conference on Increasing the High School Graduation Rate for African American Males, May 30, 2007. 
Oldenettel, Debra, \& Wordes, Madeline. (2000). The community assessment center concept. Washington, DC: U.S. Department of Justice, Office of Juvenile Justice and Delinquency Prevention.

Osher, D., Rouse, J., Quinn, M., \& Woodruff, D. (2002). Addressing invisible barriers: Improving outcomes for youth with disabilities in the juvenile justice system. College Park, MD: Center for Effective Collaboration.

Plisaka, Steven, Sherman, James, Barow, Virginia, \& Irick, Sheila. (2002). Affective disorders in juvenile offenders: A preliminary study. American Journal of Psychiatry, 157, 130-132.

Poe-Yamagata, E., \& Jones, M. (2000). And justice for some, Building Blocks for Youth, Washington DC. Available at http://www.buildingblocksforyouth.org/justiceforsome/.

Puritz, P., Burrell, S., Schwartz, R., Soler, M., \& Warboys, L. (2002). A call for justice: An assessment of access to counsel and quality of representation in delinquency proceedings. American Bar Association, Juvenile Law Center, and Youth Law Center. Available at http:/www.njdc.info/pdf/cfjfull.pdf.

Roberts, A. R. (2004). Juvenile justice sourcebook: Past, present, and future. Oxford Press.

Rosado, Lourdes, \& Shas, Riya. (2004). Protecting youth from self-incrimination when undergoing screening, assessment and treatment within the juvenile justice system. Juvenile Law Center. Available at http:// www.jlc.org/publications/3/protecting-youth-from-self-inc/.

Rosch, J., \& Lederman, C. (2006). Creating a legal and organizational context for reducing peer influence. In K. A. Dodge, T. J. Dishion, \& J. E. Landsford (Eds.), Deviant peer influences in programs for youth (pp. 141-161). New York: Guilford Press.

Shepherd, Robert E. (2003). Still seeking the promise of Gault: Juveniles and the right to counsel. Criminal Justice Magazine, 18(2). Available at http://www.abanet.org/crimjust/juvjus/cjmag/182shep.html.

Sickmund, M. (June 2006). Juvenile residential facility census, 2002: Selected findings. Juvenile Offenders and Victims National Report Series. Washington, DC: U.S. Department of Justice, Office of Justice Programs, Office of Juvenile Justice and Delinquency Prevention.

Sickmund, M., Sladky, T. J., \& Kang, W. (2004). Census of juveniles in residential placement databook. Available at http://www.ojjdp.ncjrs.org/ojstatbb/cjrp/.

Skowyra, Kathleen R., \& Cocozza, Joseph J. (2001). Blueprint for change: A comprehensive model for the identification and treatment of youth with mental health in contact with the juvenile justice system. National Center for Mental Health and Juvenile Justice. Available at http://www.ncmhjj.com/Blueprint/ default.shtml.

Stahl, Anne L. (2006). Delinquency cases in juvenile court, 2002. Washington DC: U.S. Department of Justice, Office of Juvenile Justice and Delinquency Prevention. Available at http://www.ncjrs.gov/ pdffiles1/ojjdp/fs200602.pdf.

Stroul, B., Pires, S., \& Armstrong, M. (2000). Health care reform tracking project. Louis de la Parte Florida Mental Health Institute, University of South Florida.

Sullivan, Christopher, Veysey, Bonita, Hamilton, Zachary, \& Grillo, Michele. (2007). Reducing out-of-community placement and recidivism: Diversion of delinquency youth with mental health and substance use problems from the justice system. International Journal of Offender Therapy and Comparative Criminology, 51(5), 555-577.

Teplin, Linda, Abram, Karen, McClelland, Gary, Mericle, Amy, Dulcan, Mina, \& Washburn, David. (April 2006). Psychiatric disorders of youth in detention. Juvenile Justice Bulletin. Washington DC: Office of Justice Programs, Office of Juvenile Justice and Delinquency Prevention.

Torres, Catherine, \& Ooyen, Marcel V. (2002). Briefing paper, New York: Committee on Youth Services. Available at http://webdocs.nyccouncil.info/attachments/56612.htm?CFID =1677675\& CFTOKEN=84562487.

U.S. Census Bureau, American Community Survey-Cuyahoga County. (2006). Available at http:// nodisnet1.csuohio.edu/nodis/acs.shtm.

U.S. Department of Education, Office of Special Education Programs. (OSEP, 2004). Data Analysis System, Table AA5. Available at http://www.ed.gov/about/reports/annual/osep/2003/25th-vol-1sec-1.pdf.

U.S. Department of Justice, Civil Rights Division. (2007). Marion Facility Investigation Report, May 9, 2007. Available at: http://www.usdoj.gov/crt/split/documents/marion_findlet_5-9-07.pdf.; Scioto Facility Investigation Report. Available at: http://www.usdoj.gov/crt/split/documents/ scioto_findlet_5-9-07.pdf. 
U.S. Government Accounting (now Accountability) Office. (1995). Juvenile justice representation rates varied as did counsel's impact on court outcomes. Washington DC: Author.

Washington State Institute for Public Policy. (1998). Watching the bottom line: Cost effective interventions for reducing crime in Washington. Available at http://www.teamchild.org/pdf/WSIPP.pdf.

Young, M. C., \& Gainsborough, J. (2000). Prosecuting juveniles in adult court: An assessment of trends and consequences. Washington, DC: The Sentencing Project.

Post-print standardized by MSL Academic Endeavors, the imprint of the Michael Schwartz Library at Cleveland State University, 2014 